\title{
Comparative leaf morphological analysis of 20 species of Chrysobalanaceae
}

\author{
Marcos Melo CORRÊA ${ }^{1 *}$, Veridiana Vizoni SCUDELLER², Maria Gracimar Pacheco de ARAÚJO² \\ 1 Universidade Federal do Amazonas, Programa de Pós-graduação em Diversidade Biológica, Av. Gen. Rodrigo Octávio 3000, Japiim, Manaus, AM, Brazil. 69.077-000. \\ ${ }^{2}$ Universidade Federal do Amazonas, Instituto de Ciências Biológicas - Departamento de Biologia, Av. Gen. Rodrigo Octávio 3000, Japiim, Manaus, AM. Brazil. 69.077-000 \\ * Corresponding author: marcos.melo.correa@outlook.com
}

\section{ABSTRACT}

Morphological studies focusing on vegetative traits are useful in identifying species when fertile material is not available. The aim of this study was to assess the application of comparative leaf morphology to identify species of the Chrysobalanaceae family. The morphological observations were made with a stereomicroscope. We used the diaphanization technique for viewing venation details. It is shown the descriptions of the leaf morphology, illustrations and an identification key for 20 species from genera Couepia, Licania and Parinari (Chrysobalanaceae) occurring in the Adolpho Ducke Forest Reserve, Manaus, AM, Brazil. The key was constructed using the DELTA (DEscription Language for TAxonomy) software. Leaf traits such as the presence of intersecondary venation and the type of insertion of secondary veins were recorded for each species. These morphological leaf traits are reliable for identifying species of Chrysobalanaceae.

KEYWORDS: Amazonia, identification, taxonomy.

\section{Morfologia foliar comparativa de 20 espécies de Chrysobalanaceae}

\section{RESUMO}

Estudos morfológicos com foco em caracteres vegetativos são úteis na identificação das espécies quando material fértil não está disponível. O objetivo deste estudo foi avaliar a aplicação da morfologia foliar comparativa na identificação de espécies da família Chrysobalanaceae. A caracterização morfológica foi realizada com observação em estereomicroscópio. Foi utilizada a técnica de diafanização para visualização de detalhes da venação. São apresentadas descriçóes da morfologia foliar, ilustraçóes e uma chave de identificação de 20 espécies dos gêneros Couepia, Licania e Parinari (Chrysobalanaceae) que ocorrem na Reserva Florestal Adolpho Ducke, Manaus, AM, Brasil. A chave de identificação foi construída com uso do programa DELTA (DEscription Language for TAxonomy). Caracteres foliares como a presença de nervuras intersecundárias e o tipo de inserção das nervuras secundárias foram registrados para cada espécie. Essas características foliares são confiáveis para a identificação de espécies de Chrysobalanaceae.

PALAVRAS-CHAVE: Amazônia, identificação, taxonomia. 


\section{INTRODUCTION}

Chrysobalanaceae is a pan-tropical family of trees, shrubs and lianas, consisting of 18 genera and about 530 species, and is among the most representative families in the Amazon in terms of number of species (Prance 2007, Souza and Lorenzi 2012). The species of the family have a relatively uniform external morphology (Yakandawala et al. 2010) with simple, alternate, entire, glabrous leaves (sometimes with indumentum on the abaxial surface), two glands at the base of the blade or on the petiole, two stipules, and ant-domatia are often present (Prance 1972). Species of this family are used for timber, food, and for tree planting and landscaping (Prance and Sothers 1999; Lorenzi 2002); some have medicinal properties (Carvalho and Costa 2009). In Reserva Florestal Adolpho Ducke (RFAD - Adolpho Ducke Forest Reserve), it is represented by 53 species. The reserve is a pristine forest of $100 \mathrm{~km}^{2}$, located near the city of Manaus and belongs to the Instituto Nacional de Pesquisas da Amazônia (INPA - National Institute of Amazonian Research).

Taxonomic studies with Chrysobalanaceae are usually based on floral morphological traits (Prance 1972; El
Ottra et al. 2008; Hemsing and Romero 2010). However, morphological studies focusing on vegetative traits are useful in identifying species when fertile material is not available (Cutler et al. 2011). According to Prance and Sothers (1999), vegetative characters such as stipules and glands may be effective in identifying Chrysobalanaceae species. However, they are little used in the taxonomy of the group. This study aims to analyze the leaves of 20 species of Chrysobalanaceae occurring in the Adolpho Ducke Forest Reserve, Manaus, AM, Brazil to investigate their application in the taxonomy of the group, and to provide illustrations and a key to species.

\section{MATERIALS AND METHODS}

Twenty species of Chrysobalanaceae belonging to the genera Couepia, Licania, and Parinari were studied. Voucher material of all individuals was deposited in the Herbarium of the Instituto Nacional de Pesquisas da Amazônia (INPA). Thirty leaves were collected from the second and third nodes from branches randomly sampled. Fresh material collected in the Reserva Florestal Adolpho Ducke was preferentially used. However, for Licania impressa and $L$. prismatocarpa the analyses were made from material obtained from the INPA herbarium (Table 1).

Table 1. List of species, codes, number of analyzed individuals, and voucher number of Chrysobalanaceae in the INPA herbarium used in the study.

\begin{tabular}{|c|c|c|c|}
\hline Species & Code & Individuals & Voucher no. \\
\hline Couepia canomensis (Mart.) Benth. ex Hook. f. & CCAN & 2 & INPA178329, INPA0 \\
\hline Couepia guianensis Aubl. subsp. guianensis & CGSG & 3 & INPA178327, INPA178340, INPA0 \\
\hline Couepia longipendula Pilg. & CLON & 3 & INPA178367, INPA178400, INPA178346 \\
\hline Couepia robusta Huber & CROB & 4 & INPA178397, INPA0, INPA0, INPA0 \\
\hline Couepia ulei Pilg. & CULE & 3 & INPA190963, INPA190968, INPA0 \\
\hline Licania adolphoduckei Prance & LADO & 3 & INPA189810, INPA178372, INPA178376 \\
\hline Licania apetala var. aperta (Benth) Prance & LAVA & 2 & INPA178395, INPA0 \\
\hline Licania bracteata Prance & LBRA & 2 & INPA190954, INPA0 \\
\hline Licania canescens Benoist & LCAN & 3 & INPA191044, INPA191933, INPA178377 \\
\hline Licania heteromorpha Benth var. heteromorpha & LHET & 2 & INPA191032, INPA178322 \\
\hline Licania impressa Prance & LIMP & 1 & INPA191040 \\
\hline Licania laevigata Prance & LLAE & 2 & INPA189808, INPA0 \\
\hline Licania micrantha Miq. & LMIC & 3 & INPA183371, INPA0, INPA191748 \\
\hline Licania niloi Prance & LNIL & 2 & INPA190959, INPA0 \\
\hline Licania oblongifolia Standl. & LOBL & 2 & INPA178642, INPA0 \\
\hline Licania octandra ssp. pallida (Hook.f.) Prance & LOCT & 3 & INPA178404, INPA15542, INPA0 \\
\hline Licania prismatocarpa Spruce ex Hook.f. & LPRI & 1 & INPA188277 \\
\hline Licania sandwithii Prance & LSAN & 2 & INPA178321, INPA0 \\
\hline Licania unguiculata Prance & LUNG & 3 & INPA183364, INPA178421, INPA183372 \\
\hline Parinari excelsa Sabine & PEXC & 3 & INPA178331, INPA0, INPA0 \\
\hline
\end{tabular}


For each species, the following characters were verified: outline of the petiole, shape of the stipule, shape of the lamina, venation type, color, presence and position of glands, and surface hairiness (Radford et al. 1974). Notes on venation were made using leaves that were diaphanized with $10 \%$ sodium hydroxide and stained with 1\% safranin in 50\% alcohol (Kraus and Arduin 1997), and the terminology based on Ellis et al. (2009). An identification key was constructed using the DELTA (Description Language for Taxonomy) software (Dallwitz et al. 1999). The illustrations were made in ink, with material examined under a stereomicroscope.

\section{RESULTS}

The species analyzed had the basic morphological pattern described for the family (Prance 1972,1989). Leaves were petiolate, simple, alternate distichous, with stipules usually present in younger branches. Some species had trichomes on the abaxial surface. The predominant format of the lamina was elliptical, represented by eight species. The margin was usually entire, being slightly revolute in Licania impressa and clearly revolute in $L$. niloi. The base of the lamina was variable with predominant decurrent shape, with the apex acuminate in most cases. Details for each species are shown in Table 2 and illustrated in Figures 1 to 5.

Table 2. Leaf morphological characteristics analyzed for 20 species of Chrysobalanaceae from the Adolpho Ducke Forest Reserve, Manaus - AM. DES AREOLES: areoles development, PAR SV: pairs of secondary veins, INS SV: insertion of secondary veins (ex $=$ excurrent, dec $=$ decurrent), INT VEIN: intersecondary veins ( $A=$ absent, $P=$ present), POS TRIC: position of trichomes.

\begin{tabular}{|c|c|c|c|c|c|c|c|c|c|c|c|c|}
\hline $\begin{array}{l}\text { SPECIES } \\
\text { CODE }\end{array}$ & VENATION & $\begin{array}{c}\text { DES } \\
\text { AREOLES }\end{array}$ & VENULES & $\begin{array}{l}\text { PAR } \\
\text { SV }\end{array}$ & $\begin{array}{l}\text { INS } \\
\text { SV }\end{array}$ & $\begin{array}{l}\text { INT } \\
\text { VEIN }\end{array}$ & LAMINA & BASE & APEX & GLANDS & STIPULES & POS TRIC \\
\hline CCAN & eucamptodromous & moderate & dendritic & $13-15$ & ex & A & elliptic & round & acuminate & absent & linear & abaxial \\
\hline CGSG & mixed & good & unbranched & $13-15$ & ex & A & elliptic & acute & acuminate & leaf base & linear & abaxial \\
\hline CLON & eucamptodromous & moderate & dendritic & $7-8$ & ex & $P$ & $\begin{array}{l}\text { ovate to } \\
\text { oblong }\end{array}$ & decurrent & acuminate & leaf base & lanceolate & glabrous \\
\hline CROB & eucamptodromous & good & unbranched & $20-21$ & ex & $P$ & $\begin{array}{l}\text { elliptic to } \\
\text { oblong }\end{array}$ & cordate & acuminate & absent & lanceolate & abaxial \\
\hline CULE & brochidodromous & good & unbranched & $11-12$ & ex & $P$ & elliptic & round & acuminate & $\begin{array}{c}\text { axils of } \\
\text { secondary veins }\end{array}$ & linear & abaxial \\
\hline LADO & mixed & moderate & dendritic & $13-15$ & dec & $P$ & $\begin{array}{l}\text { obovate } \\
\text { to oblong }\end{array}$ & decurrent & acuminate & along the lamina & lanceolate & glabrous \\
\hline LAVA & brochidodromous & moderate & dendritic & $11-12$ & ex & $P$ & ovate & decurrent & acuminate & $\begin{array}{l}\text { base margin, } \\
\text { along the lamina }\end{array}$ & linear & glabrous \\
\hline LBRA & eucamptodromous & good & dendritic & $11-12$ & ex & A & ovate & subcordate & acute & absent & lanceolate & abaxial \\
\hline LCAN & mixed & poor & dendritic & $9-10$ & dec & $P$ & lanceolate & cuneate & acuminate & absent & linear & glabrous \\
\hline LHET & eucamptodromous & moderada & dendritic & $7-8$ & dec & $P$ & elliptic & decurrent & round & $\begin{array}{l}\text { petiole apex, } \\
\text { along the lamina }\end{array}$ & lanceolate & glabrous \\
\hline LIMP & eucamptodromous & poor & dendritic & $9-10$ & ex & A & elliptic & round & acuminate & middle of petiole & linear & abaxial \\
\hline LLAE & eucamptodromous & moderada & dendritic & $7-8$ & dec & $P$ & $\begin{array}{l}\text { obovate } \\
\text { to elliptic }\end{array}$ & decurrent & acuminate & along the lamina & linear & glabrous \\
\hline LMIC & eucamptodromous & moderada & dendritic & $5-6$ & dec & A & elliptic & decurrent & acuminate & leaf base & linear & abaxial \\
\hline LNIL & mixed & poor & dendritic & $11-12$ & dec & $P$ & $\begin{array}{l}\text { ovate to } \\
\text { oblong }\end{array}$ & decurrent & acuminate & base margin & linear & abaxial \\
\hline LOBL & eucamptodromous & moderada & dendritic & $9-10$ & dec & $P$ & oblong & subcordate & round & leaf base & linear & glabrous \\
\hline LOCT & eucamptodromous & moderada & dendritic & $9-10$ & dec & $P$ & elliptic & decurrent & acuminate & petiole apex & linear & abaxial \\
\hline LPRI & eucamptodromous & poor & dendritic & $5-6$ & dec & $P$ & obovate & acute & round & leaf base & lanceolate & glabrous \\
\hline LSAN & eucamptodromous & poor & dendritic & $11-12$ & ex & A & $\begin{array}{l}\text { obovate } \\
\text { to elliptic }\end{array}$ & round & acuminate & absent & elliptic & abaxial \\
\hline LUNG & mixed & poor & dendritic & $9-10$ & dec & $P$ & ovate & decurrent & acuminate & petiole apex & lanceolate & $\begin{array}{c}\text { ab.surface } \\
\text { of primary } \\
\text { vein }\end{array}$ \\
\hline PEXC & eucamptodromous & poor & dendritic & $23-25$ & dec & $P$ & elliptic & round & acuminate & middle of petiole & elliptic & abaxial \\
\hline
\end{tabular}




\section{Glands}

Glands occurred only at the base of the lamina in C. guianensis subsp. guianensis, C. longipendula, L. micrantha, L. niloi, $L$. oblongifolia, and L. prismatocarpa (Figure 1B - C, 4A - C, 5A). They were found in the axils of secondary veins in $C$. ulei (Figure $2 \mathrm{~A}$ ) and distributed on the lamina in $L$. adolphoduckei and $L$. laevigata (Figure 2B, 3D). In L. apetala var. aperta, the glands occured at the margin of the base and on the lamina (Figure 2C). In $L$. heteromorpha var. heteromorpha they were found at the apex of the petiole and on the lamina (Figure 3B), in L. impressa and P. excelsa glands occurred in the middle of the petiole (Figure 3C, 5D). The glands occured at the apex of the petiole in L. octandra subsp. pallida and L. unguiculata (Figure 4D, 5C).

\section{Stipules}

Stipules were found in all species but they were generally deciduous and had varying shapes, with the linear shape predominating (Figure 6A-B, E, G, I, K-P). Lanceolate stipules occured in C. longipendula, $C$. robusta, $L$. adolphoduckei, L. bracteata, L. heteromorpha, L. prismatocarpa and L. unguiculata (Figure 6C-D, F, H, J, Q, S). Elliptic stipules were only found in $L$. sandwithii and $P$. excelsa (Figure 6R, T). Licania apetala var. aperta and L. laevigata were collected only with the bases of the stipules present in the branch (Figure 6G and L).

\section{Venation}

The most common venation pattern in the studied species was the eucamptodromous (Figure 7A, D), with the occurrence of eucamptodromous leaves which become brochidodromous near the apex, here called mixed venation (Table 2) in some species (Figure 7C). Exceptions in this study occured in C. ulei and L. apetala var. aperta, which had a camptodromous-brochidodromous pattern (Figure 7B).

\section{Identification key to 20 species of Chrysobalanaceae from the Reserva Florestal Adolpho Ducke}

1. Linear stipules................................................................2

Lanceolate stipules..........................................................

Elliptic stipules...........................................................

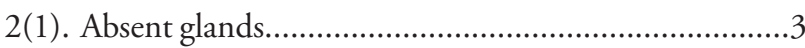

Glands distributed in lamina............Licania laevigata

Glands restricted to the margin of the base.

Licania niloi

Glands in the margin of the base and the margin of the lamina..... Licania apetala var. aperta

Glands in the middle of the petiole...

Licania impressa

Glands in the apex of the petiole.

Licania octandra subsp. pallida
Glands in the base of the lamina..................................... 4

Glands in the axils of secondary veins.........Couepia ulei

3(2). Present intersecondary veins; central vein with convex adaxial surface; eucamptodromous / brochidodromous mixed venation. Licania canescens

Absent intersecondary veins; central vein with concave adaxial surface; eucamptodromous venation.

Couepia canomensis

4(2). Areoles with irregular shape and size; subcordate base; 9-10 pairs of secondary veins.

Licania oblongifolia

Areoles with irregular shape and regular size; decurrent base; 5-6 pairs of secondary veins.....Licania micrantha Areoles with regular shape and size; acute base; 13-15 pairs of secondary veins.

Couepia guianensis subsp. guianensis

5(1). Obovate-oblong lamina..............Licania adolphoduckei

Ovate lamina...............................................................6

Elliptical lamina..........................Licania heteromorpha

Elliptic-oblong lamina........................... Couepia robusta

Ovate-oblong lamina....................Couepia longipendula

Obovate- elliptic lamina..............Licania prismatocarpa

6(5). Present intersecondary veins; areoles with irregular shape and size, eucamptodromous / brochidodromous mixed venation; central vein with convex adaxial surface.

Licania unguiculata

Absent intersecondary veins; areoles with regular shape and size; eucamptodromous venation; central vein with concave adaxial surface.

Licania bracteata

7(1). Present intersecondary veins; central vein with concave adaxial surface; glands in the middle of the petiole

Parinari excelsa

Absent intersecondary veins, central vein with convex adaxial surface; absent glands.

Licania sandwithii

Secondary veins had excurrent insertion in all species of Couepia analyzed, in Licania most had decurrent insertion, and in Parinari excelsa the insertion was also decurrent (Table 2). Simple intersecondary veins occured in several species and tertiary veins followed the percurrent model, with variations in orientation through the intercostal area forming obtuse angles with reference to the central vein. Venules generally formed dendritic branches (Figure 7, E, G-H), with unbranched venules also occurring in C. guianensis subsp. guianensis (Figure 7F), C. robusta and C. ulei. The unbranched pattern did not occur in Licania. Areoles formed patterns ranging from poor (irregular size and shape), moderate (regular size and irregular shapes) and well developed (regular size and shape). 


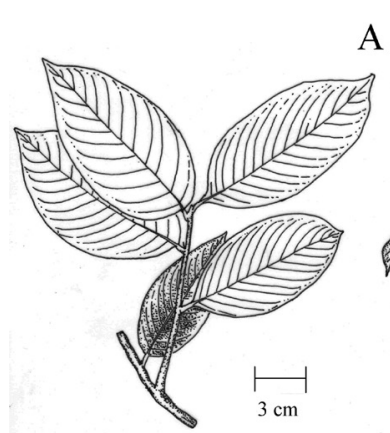

A
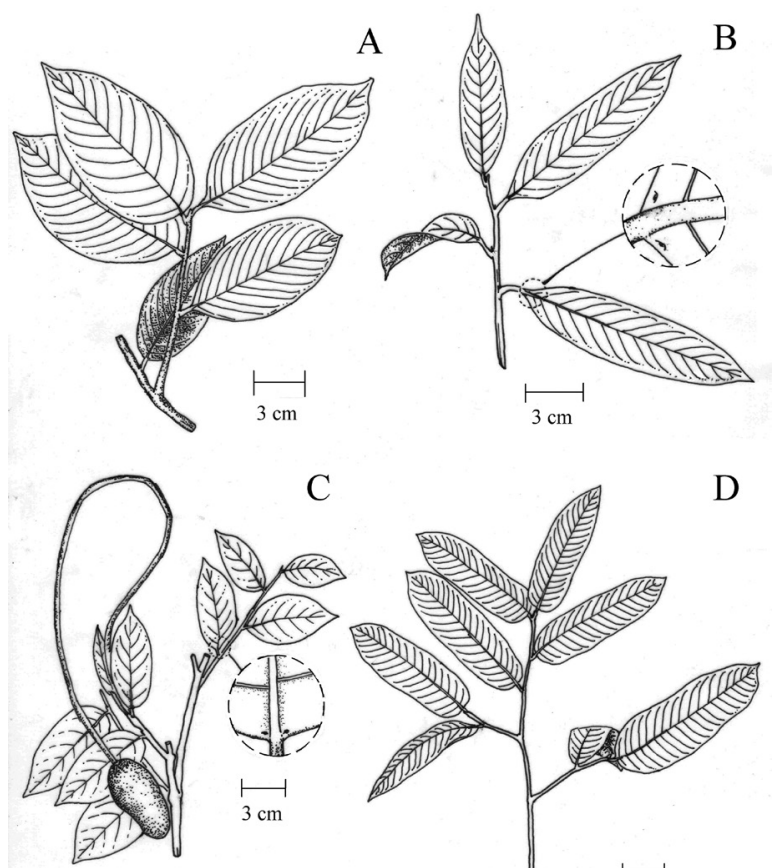

C

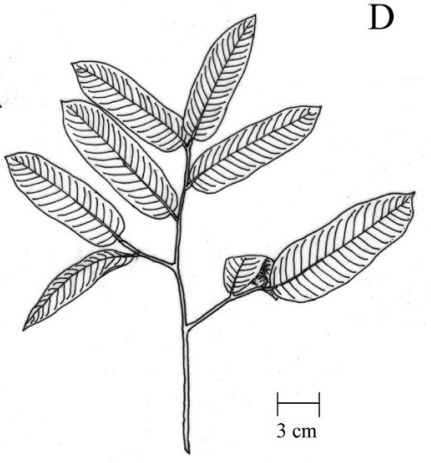

Figure 1. Habit and position of glands. A. Couepia canomensis, B. C. guianensis subsp. guianensis, C. C. Iongipendula and D. C. robusta.
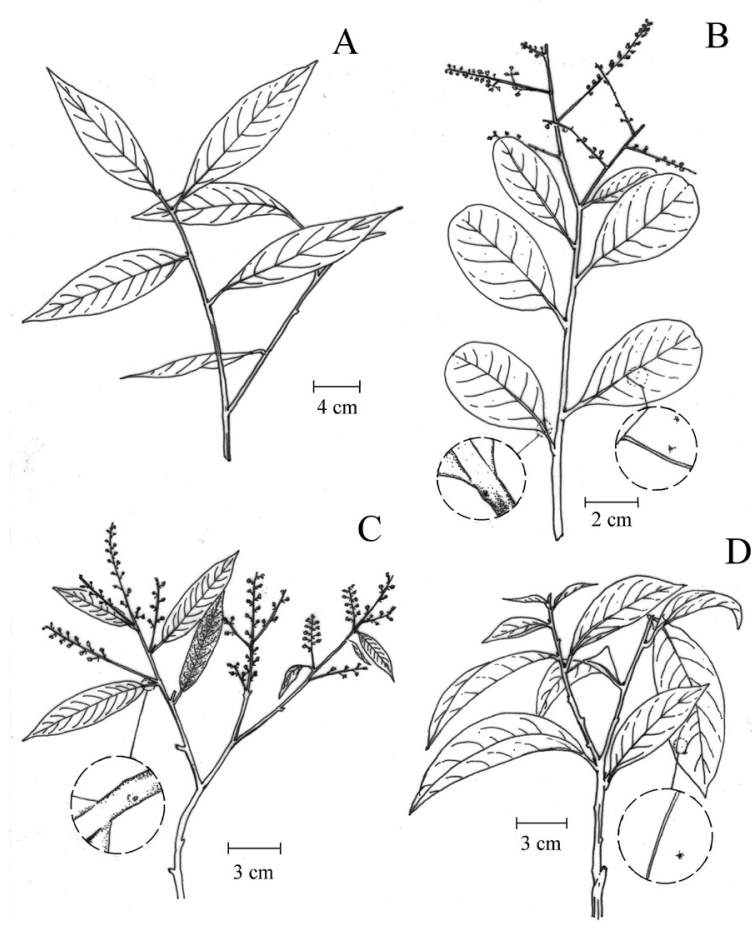

Figure 3. Habit and position of glands. A. Licania canescens, B. L. heteromorpha var. heteromorpha, C. L. impressa and D. L. laevigata.
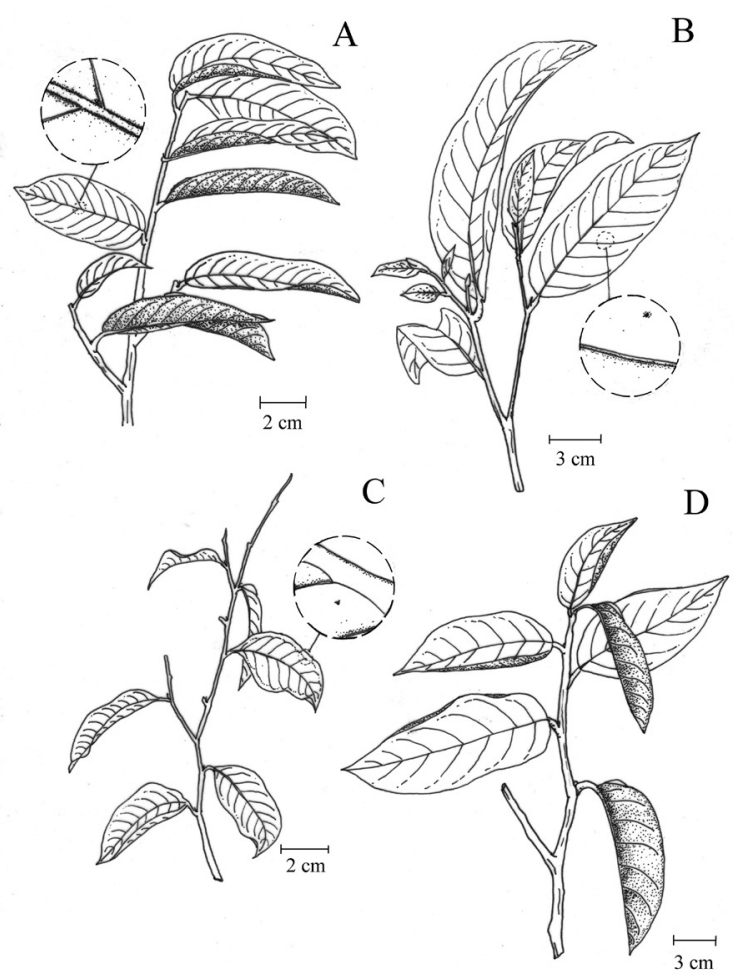

Figure 2. Habit and position of glands. A. Couepia ulei, B. Licania adolphoduckei, C. L. apetala var. aperta and D. L. bracteata.

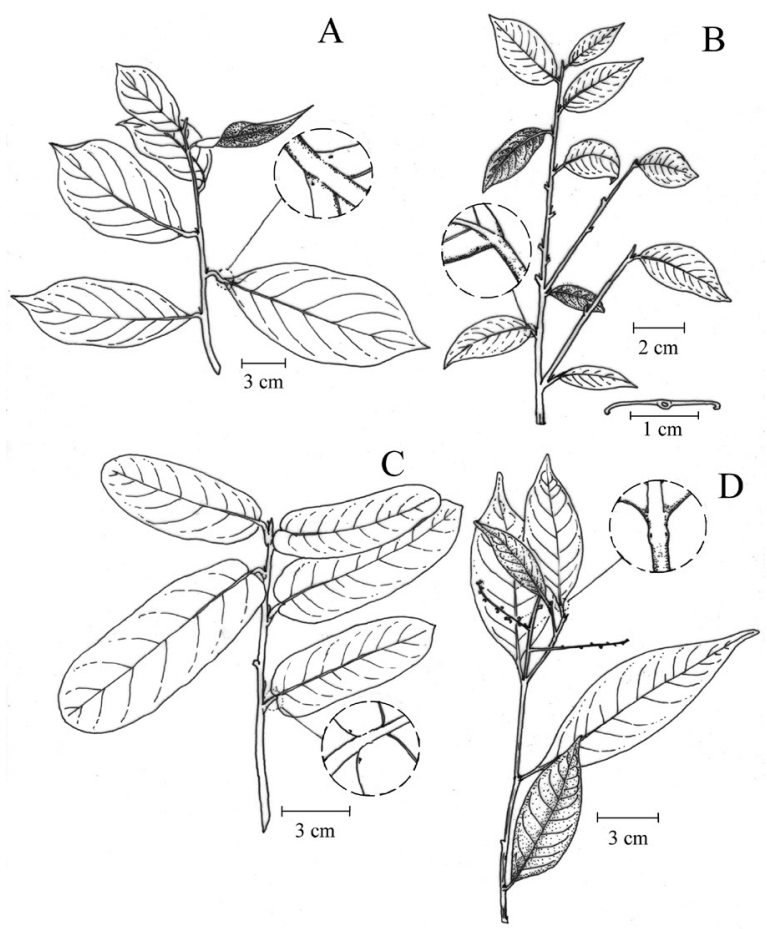

Figure 4. Habit and position of glands. A. Licania micrantha, B. L. niloi, C. L. oblongifolia and D. L. octandra subsp. pallida. 


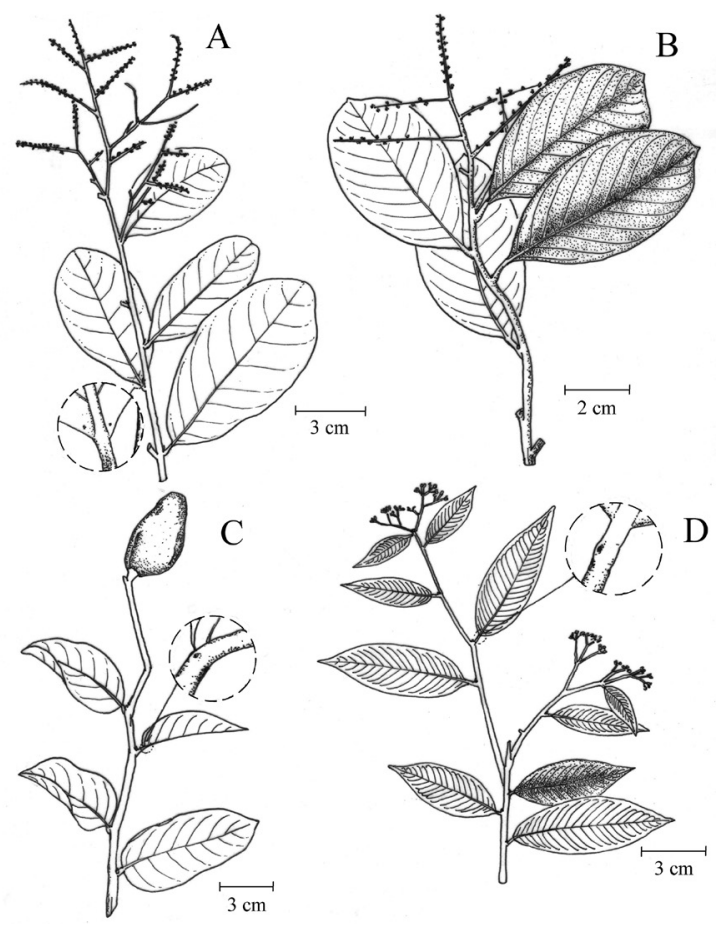

Figure 5. Habit and position of glands. A. Licania prismatocarpa, B. L. sandwithii, C. L. unguiculata and D. Parinari excelsa.
2.

$+\sqrt{0.5 \mathrm{~cm}} \stackrel{\mathrm{E}}{\stackrel{\mathrm{F}}{\rightleftarrows}}$

If

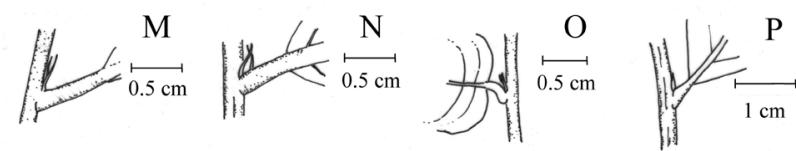

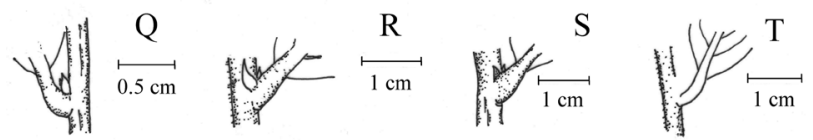

Figure 6. Detail of the stipules. A. Couepia canomensis, B. C. guianensis subsp. guianensis, C. C. longipendula, D. C. robusta, E. C. ulei, F. Licania adolphoduckei, G. L. apetala var. aperta, H. L. bracteata, I. L. canescens, J. L. heteromorpha var. heteromorpha, K. L. impressa, L. L. laevigata, M. L. micrantha, N. L. niloi, O. L. oblongifolia, P. L. octandra subsp. pallida, Q. L. prismatocarpa, R. L. sandwithii, S. L. unguiculata, T. Parinari excelsa.

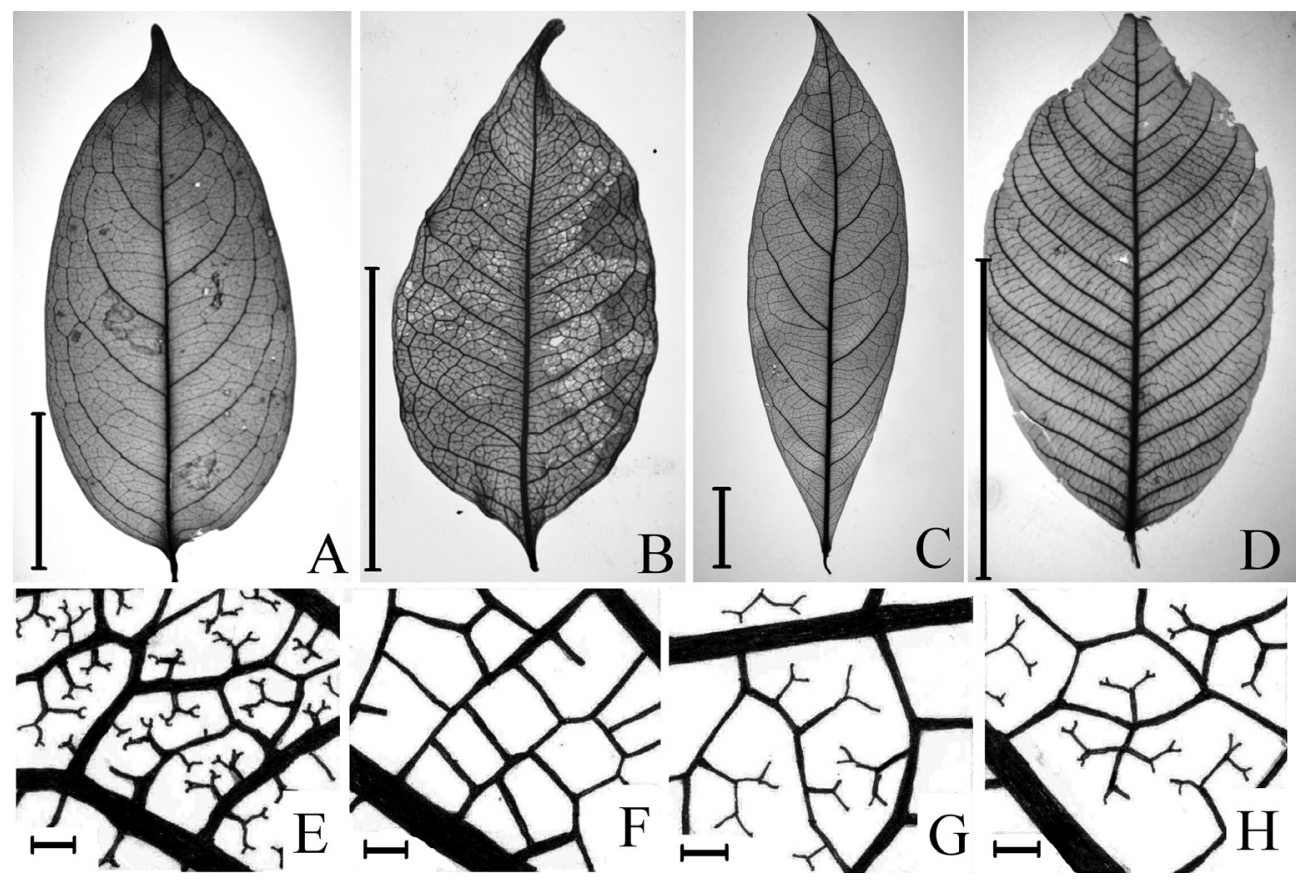

Figure 7. Venation pattern and development of the areoles of Chrysobalanaceae. A. Couepia longipendula, B. Licania apetala var. aperta, C. L. canescens, D. Parinari excelsa. Areole development in E. Couepia canomensis, F. C. guianensis subsp. guianensis, G. Licania adolphoduckei, H. Parinari excelsa. Eucamptodromous venation in A, D; brochidodromous in B; eucamptodromous / brochidodromous in C. Areoles with moderate development in $E$, G; well developed in F; poor developed in H. Dendritic venules occur in E, G and H; unbranched in F. Scale bar: A-D: $3 \mathrm{~cm}$; E-H: $200 \mu \mathrm{m}$. 


\section{DISCUSSION}

In this study, morphological traits such as the shape of the lamina, type of stipules and the presence and position of the glands vary between species and aid in the identification of some Chrysobalanaceae. According to Prance (2007), Licania leaves are oblong-elliptic to oblong-lanceolate, abaxially glabrous when fully expanded and, when they are young they have deciduous indumentum. Indumentum on the abaxial surface occurred in several species, present in mature leaves and with woolly appearance in young leaves. In Licania tomentosa, Monteiro et al. (2011) attribute the woolliness of the leaf to extensive twining of simple trichomes.

In earlier studies focused on vegetative characters (Braz et al. 2004), the position of the stipules was used to separate species of Chrysobalanaceae from species of other families and the differentiation among species of this family was based on the shape of the lamina and of the base, and on the number of secondary veins. Deciduous stipules have already been observed in C. robusta, C. ulei, L. heteromorpha, L. laevigata, L. prismatocarpa and $P$. excelsa (Prance 2007). However, in this study, they were all collected with stipules. There seems to be no relation between the shape of stipules and other characteristics of the leaf. Species with the same shape of lamina or glands in the same position (or even absent) did not exhibit the same type of stipule (Table 2). Although five species show no obvious glands, Prance and Sothers (1999) recorded glands in these species.

The commonest venation pattern in species of Chrysobalanaceae in this study is the camptodromouseucamptodromous. Here, the species with mixed venation are brochidodromous near the apex, following the terminology of Ellis et al. (2009) for eucamptodromous leaves whose secondary veins enter directly into contact near the apical region. These authors also described eucamptodromous venation with intersecondary veins for Couepia paraensis, and for Licania michauxii the type of venation is the brochidodromous without intersecondary venation, a pattern not registered here. Areoles vary from poor to well developed, with varying sizes. Similar results were found by Araújo et al. (2010) in Malpighiaceae, which terminology is based on the size and branching within the areoles.

Licania apetala var. aperta is the only species with the same color on both sides of the lamina. This feature is not associated with a particular genus, as it was reported by Hemsing and Romero (2010) in Hirtella gracilipes and Licania humilis. No exclusive characters were observed for any genus, probably due to the low number of species per genus analyzed in this study. However, the phylogenetic analysis of Yakandawala et al. (2001), which used morphological characters, suggests that Licania is a paraphyletic genus, as well as the tribal groupings defined by Prance and White (1988), highlighting the need for further taxonomic studies on this plant group.
The species analyzed have a slightly dull sheen on the leaves, a feature that was not included among those used in the identification key due to variation between individuals of the same species and the fact that $L$. impress $a$ and $L$. prismatocarpa were analyzed from herbarium material. According to Solereder (1908), the semi-metallic sheen on leaves of many Chrysobalanaceae is caused by the presence of silica in the cell walls of the leaf epidermis.

\section{CONCLUSIONS}

Characters such as the presence of intersecondary veins and insertion type of secondary veins have not been reported in species prior to this study and were useful in the segregation of the species. Thus, in general, the vegetative traits, when taken together are reliable for identifying species of Chrysobalanaceae. These morphological leaf traits can be observed throughout the year, regardless of the reproductive stage of the species.

\section{ACKNOWLEDGEMENTS}

To the Fundação de Amparo à Pesquisa do Estado do Amazonas (FAPEAM - Foundation for Research Support of the State of Amazonas) for granting the master's student scholarship and research funding, to the field auxiliary Thiago Marinho (Taco) for his assistance with the collection, to the researcher Michael John Gilbert Hopkins, for his assistance with the revision of this manuscript, and to the Laboratório de Botânica Agroflorestal (Labaf - Agroforestry Botanical Laboratory) staff for the space and equipment used during the study.

\section{REFERENCES}

Araújo, J.S.; Azevedo, A.A.; Silva L.C.; Meira, R.M.S.A. 2010. Leaf anatomy as an additional taxonomy tool for 16 species of Malpighiaceae found in the Cerrado area. (Brazil). Plant Systematics and Evolution, 286:117-131.

Braz, D.M.; Moura, M.V.L.P.; Rosa, M.M.T. 2004. Chave de identificação para as espécies de Dicotiledôneas arbóreas da Reserva Biológica do Tinguá, RJ, com base em caracteres vegetativos. Acta Botanica Brasilica, 18: 225-240.

Carvalho, M.G.; Costa, P.M. 2009. Outros constituintes isolados de Licania arianeae (Chrysobalanaceae). Revista Brasileira de Farmacognosia, 19: 290-293.

Cutler, D.F; Botha, T.; Stevenson, D.S. 2011. Anatomia vegetal: uma abordagem aplicada. Artmed, Porto Alegre, Rio Grande do Sul. 304p.

Dallwitz, M.J.; Paine, T.A.; Zurcher, E.J. 1999. User's guide to the DELTA Editor. (http://delta-intkey.com) Accessed on $10 / 01 / 2013$

Ellis, B.; Daly D.C.; Hickey, L.J.; Johnson, K.R.; Mitchell J.D.; Wilf, P.; Wing, S.L. 2009. Manual of Leaf Architecture. Cornell University Press, Ithaca, New York. 190p. 
El Ottra, J.H.L.; Pirani, J.R.; Prance, G.T. 2008. Flora da Serra Do Cipó, Minas Gerais: Chrysobalanaceae. Boletim de Botânica da Universidade de São Paulo, 26: 155-160.

Hemsing, P.K.B.; Romero, R. 2010. Chrysobalanaceae do Parque Nacional da Serra da Canastra, Minas Gerais, Brasil. Rodriguésia, 61: 281-288.

Kraus, J.E.; Arduin, M. 1997. Manual básico de métodos em morfologia vegetal. Edur, Seropédica, Rio de Janeiro. 198p.

Lorenzi, H. 2002. Árvores brasileiras: manual de identificação e cultivo de plantas arbóreas do Brasil. 4.ed. Instituto Plantarum, Nova Odessa, São Paulo. 199p.

Monteiro, K.L.; Oliveira, C.; Silva, B.M.S.; Môro, F.V.; Carvalho, D.A. 2011. Caracterização morfológica de frutos, de sementes e do desenvolvimento pós-seminal de Licania tomentosa (Benth.) Fritsch. Ciência Rural, 42: 90-97.

Prance, G.T. 1972. Monograph of Chrysobalanaceae. Flora Neotropica, 9: 1-406.

Prance, G.T. 1989. Flora Neotropica Monograph no. 9 Supplement. Chrysobalanaceae. Flora Neotropica, 9 (Supplement): 1-267.

Prance, G.T. 2007. Flora da Reserva Ducke, Amazonas, Brasil: Chrysobalanaceae. Rodriguésia, 58: 493-531.

Prance, G.T.; Sothers, C.A. 1999. Chrysobalanaceae. In Ribeiro, J.E.L.S.; Hopkins, M.J.G.; Vicentini, A.; Sothers, C.A.; Costa, M.A.S.; Brito, J.M. et al. Flora da Reserva Ducke: guia de identificação das plantas vasculares de uma floresta de terra-firme na Amazônia Central. INPA, Manaus. 816p.

Prance, G.T.; White, F. 1988. The Genera of Chrysobalanaceae: A study in practical and theoretical taxonomy and its relevance to evolutionary biology. Transactions of the Royal Society of London, 320: 1 -184.

Radford, A.E.; Dickinson, W.C.; Massey, J.R.; Bell, R. 1974. Vascular plant systematics. Harper \& Row, New York. 891p.

Solereder, H. 1908. Systematic anatomy of the dicotyledons. A handbook for laboratories of pure and applied Botany. v.2. Clarendon Press, Oxford. 1182p.

Souza, V.C.; Lorenzi, H. 2012. Botânica Sistemática: guia ilustrado para identificação das famílias de Fanerógamas nativas e exóticas no Brasil, baseado em APGIII. 3. ed. Instituto Plantarum, Nova Odessa, São Paulo. 768p.

Yakandawala, D.; Morton, C.M.; Prance, G.T. 2001. A phylogenetic study of the Chrysobalanaceae using morphological data. Ceylon Journal of Science (Biological Sciences), 28: 1-17.

Yakandawala, D.; Morton, C.M.; Prance, G.T. 2010. Phylogenetic relationships of the Chrysobalanaceae inferred from chloroplast, nuclear, and morphological data. Annals of the Missouri Botanical Garden, 97: 259-281.

Recebido em 11/03/2014

Aceito em 28/05/2014 